$\begin{array}{llllllllll}\mathbf{Z} & \mathbf{Z} & \mathbf{A} & \mathbf{G} & \mathbf{R} & \mathbf{A} & \mathbf{N} & \mathbf{I} & \mathbf{C} & \mathbf{Y}\end{array}$

PRZEGLĄD BIBLIOTECZNY 2019 z. 2

PL ISSN 0033-202X

NIKOŁAJ ZUBKOW

Dział Naukowo-Badawczy

Biblioteka Literatury Zagranicznej

im. M. Rudomino w Moskwie

e-mail: nnzubkov@rambler.ru

\title{
SPECYFIKA BIBLIOTEKI I JEJ MOŻLIWE ZADANIA ${ }^{1}$
}

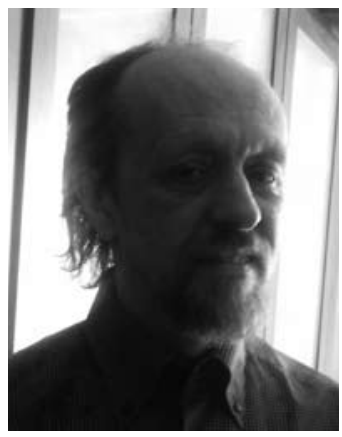

Nikołaj Zubkow, kandydat (tj. dr) nauk filologicznych, główny specjalista w Dziale Naukowo-Badawczym Biblioteki Literatury Zagranicznej im. M. Rudomino w Moskwie.

SŁOWA KLUCZOWE: Biblioteka i jej specyfika. Informacja. Kształcenie bibliotekarzy. Prognozowane zadania bibliotek.

ABSTRAKT: W tekście podejmuję próbę rozróżnienia pomiędzy biblioteką tradycyjną a wirtualna, ze wskazaniem zalet bibliotekarstwa tradycyjnego, również we współczesnej rzeczywistości. Przedstawiam też propozycję organizacji biblioteki jako ośrodka kultury książki.

W obecnych dyskusjach na temat zadań bibliotek przeważają sugestie - według mnie: mniej lub bardziej podkreślające - dostosowania ich do wysoce zmiennych okoliczności bieżących. Znacznie rzadziej natomiast pojawia się pytanie, czy biblioteka jako instytucja nie posiada w swojej strukturze autonomicznych instrumentów własnych, które mogłaby społeczeństwu zaoferować, dla ogólnego pożytku.

Historycznie rzecz ujmując, biblioteka zawsze była miejscem gromadzenia oraz czytania publikacji, a mówiąc (teraz i później) konkretniej, chociaż w uproszczeniu, książek. Oczywiście poza tym dla funkcjonowa-

${ }^{1}$ Tekst oryginalny w: Rumiancewskije cztienija '18. T. 1. Moskwa: Paszkow dom, 2018, s. 317-321. 
nia bibliotek niezbędni byli użytkownicy, a także obsługujący ich bibliotekarze.

$\mathrm{W}$ ten sposób konstytuuje się model komunikacji przez bibliotekę, złożony z czterech składników: tekst > książka > bibliotekarz > czytelnik. Który można łatwo odnieść do uproszczonego, ogólnego modelu procesu komunikacji: informacja > nośnik > kanał relacji > odbiorca. Dopowiem jeszcze, że w takim ujęciu książkę najlepiej rozumieć jako obiekt złożony - z materialnego nośnika i z treści.

$\mathrm{Z}$ zasygnalizowanego tu modelu komunikacji bibliotecznej nie można oczywiście wyeliminować informacji (treści), bo wówczas cały proces straciłby wszelki sens. Nośnik bowiem stałby się wtedy po prostu jakimś nieprzezroczystym przedmiotem, użytkownik - kimkolwiek, ale bez właściwości, zaś kanał relacji nie tworzyłby żadnych powiązań.

Natomiast, jeżeli ktoś bardzo chciałby, to może wykluczyć z tego modelu użytkownika. Po co - to już inna sprawa. No bo jednak biblioteka pozostaje biblioteką, nawet jeżeli nie jest dla publiczności dostępna (choćby z powodu remontu), niezależnie od tego, jak długo taka sytuacja trwa. Jakkolwiek normalne to oczywiście nie jest.

Z kolei w innym ujęciu: pracownicy bibliotek, wkomponowani w kanał transmisji treści, występują jako personel usługowy. Otóż rzecz w tym, że zapotrzebowanie na określoną kadrę usługową z upływem czasu ulega zmianie, $z$ różnych powodów. Obecnie można wyobrazić sobie teoretycznie bibliotekę, ewentualnie w pełni zautomatyzowaną, także w sferze usługowej.

Powstaje natomiast pytanie, czy z przedstawionego modelu komunikacji bibliotecznej (więc i biblioteki jako takiej), można wyeliminować materialny nośnik treści (informacji), lub - mówiąc dokładniej - czy jest możliwa biblioteka bez książek. Otóż nie brak opinii, że istotnie można przechowywać informacje bez takiego nośnika. Takie są fakty. Ale zarazem: taki jest problem.

Rzeczywiście można wyobrazić sobie - i nieraz tak bywa - że biblioteka czysto wirtualna pozostaje nadal biblioteka, a nawet że przyszłość biblioteki jako instytucji opiera się na postępującej wirtualizacji. Ale to jednak nie jest oczywistość i nie ma na to solidnego dowodu. Dlatego trzeba poddać refleksji inny wariant prospektywny: mianowicie że biblioteka wirtualna, oraz biblioteka tradycyjna, to są jednak odmienne rozwiązania instytucjonalne .

Zwracam uwagę, że w ogóle istnieją też takie systemy informacyjne, dla których wyłączność nośników fizycznych jest oczywista. To te, które - z wielu zresztą powodów - wymienia się zwykle obok systemów bibliotecznych, mianowicie kreowane przez archiwa oraz przez muzea. Bo też są pomiędzy nimi liczne podobieństwa.

Jak już wspomniałem, w szczególnych okolicznościach biblioteka teo- 
retycznie mogłaby istnieć bez użytkowników. Dla archiwów taka sytuacja jest właściwie normalna, chociaż niekoniecznie pożądana. Natomiast muzea, podobnie jak biblioteki, można czasem zamknąć, jeśli to konieczne, a potem uruchomić powtórnie.

Tego rodzaju funkcjonowanie, $\mathrm{z}$ ewentualnymi przerwami w użytkowaniu, jest możliwe za sprawą fizycznych nośników treści. Ponieważ tylko one gwarantują dostawę informacji zarówno bieżących, jak i archiwalnych, tak w trybie bieżącym, jak i z odtworzeniem po czasie. Gdyby zatem nawet zniknęli nagle wszyscy odbiorcy określonych treści, to same te treści - dzięki nośnikom fizycznym - pozostaną zachowane i, po ewentualnym odświeżającym rozszyfrowaniu, mogą być ponownie użytkowane. W końcu przecież tak właśnie reanimuje się zabytkowe materiały piśmiennicze.

$\mathrm{W}$ odniesieniu do informacji wirtualnych natomiast, sytuacja wydaje się inna. Żeby rozszyfrować treść zarejestrowaną na nośniku fizycznym wystarczy znać kod. Tymczasem do odczytania treści z nośnika wirtualnego potrzeba ponadto urządzenia, które będzie miało ten kod wewnętrznie wmontowany. To w każdym razie znaczy, że materiały informacyjne przechowywane na nośnikach fizycznych należą jednak do innej kategorii zasobów komunikacyjnych aniżeli materiały informacyjne funkcjonujące poza takimi nośnikami. Terminologiczna dokładność wymagałaby nawet, być może, odstąpienia od nazwy biblioteka przy ewentualnej mnogości zasobów wirtualnych.

Nie brak obiegowych opinii, że kolekcje wirtualne $\mathrm{z}$ czasem będą w stanie wyeliminować biblioteki tradycyjne. Ale wobec tego warto zadać z kolei pytanie, czy aby te biblioteki dotychczasowe rzeczywiście wyczerpały już cały swój arsenał. Czy mianowicie nie posiadają takich atrybutów oraz możliwości, których nie da się zastąpić w żaden inny sposób. Inaczej mówiąc: czy nie pozostają nadal w jakiś sposób konkurencyjne.

Dbając o zwięzłość tej wypowiedzi, nie będę już rozwijał krytycznej opinii na temat prognoz rozwoju bibliotekarstwa, które aktualnie uchodzą za dominujące. Przypomnę tylko, że ich zasadniczy sens sprowadza się do zapewnienia użytkownikom dostępu do materiałów elektronicznych, zarówno na miejscu, w bibliotece, jak też poza nią, więc w trybie online. No i wobec tego nieodzowna jest digitalizacja wszystkich rozpowszechnianych materiałów.

Kwestionowanie ogólnych zalet Internetu nie miałoby najmniejszego sensu: widać je wszak gołym okiem. Jednak w zakresie gromadzenia i rozpowszechniania treści, sieć komputerowa ujawnia też poważną niedogodność. Mianowicie lokalizowana w niej zawartość nie podlega automatycznej strukturalizacji.

Tymczasem wiadomo, że nowe treści można wygenerować - wprawdzie na wiele różnych sposobów - jednak wyłącznie w oparciu o ustruk- 
turalizowane zasoby treści już istniejących. Żeby więc pozyskiwanie treści nowych nie miało charakteru wyłącznie jednostkowego, przypadkowego, a tym samym bezużytecznego, musi funkcjonować specjalne instrumentarium oraz odpowiedni ośrodek, przejmujący rozproszone treści z nieuporządkowanej podaży i przyporządkowujący je do stosownych struktur.

Być może byłoby to możliwe automatycznie, w ramach wewnętrznych procesów elektronicznych, gdyby odpowiedni program wykreowano od samych początków digitalizowania treści. Obecnie jednak niebywały ilościowy rozrost treści, częściowo zresztą również powtarzalnych, przewyższa tempo oraz możliwości postępu technicznego.

Żeby wprowadzić jakiekolwiek uproszczenia w tym zakresie, niezbędna byłaby możliwość wyszukiwania i opracowania treści (informacji), ale nie w całej komunikacyjnej magmie, lecz w obrębie cząstkowych klastrów. Otóż niczego takiego nie widać. Wychodzi więc na to, że strukturyzacja komunikacji digitalnej - $\mathrm{w}$ dającej się przewidzieć przyszłości lub może nawet w ogóle - pozostanie do realizacji w trybie offline.

Dotychczas uporządkowana transmisja treści, pozostających $\mathrm{w}$ powszechnym obiegu, należała do powinności instytucji edukacyjnych na wszystkich poziomach, więc szkół oraz uczelni, a realizacją zajmowali się nauczyciele oraz/lub wykładowcy. Teraz jednak taka strukturyzacja wiedzy w wykonaniu pośredników edukacyjnych okazuje się wyjątkowo trudna. Zadanie jest zbyt skomplikowane, żeby mógł poradzić sobie z nim indywidualnie jakikolwiek nauczyciel albo wykładowca w ramach lekcji bądź wykładu. Tym trudniej o uporządkowaną rekonstrukcję w tym trybie jakiegoś szerszego obszaru wiedzy.

Zresztą sama instytucja szkoły oraz uczelni uległa rozmaitym przekształceniom strukturalnym i takiego zadania realizować nie jest teraz w stanie. Dlatego wydaje się, że strukturyzacją treści (informacji, wiedzy), skierowanych do ogólnospołecznego użytku, powinny zajmować się biblioteki.

Przebieg takiego przedsięwzięcia jest akurat dla nas stosunkowo łatwy do wyobrażenia. Ponieważ to właśnie w bibliotekarstwie wiadomo w jaki sposób zasoby treści nieuporządkowanych można wkomponować w istniejącą już treściową strukturę przedmiotową. Mogliby więc zająć się tym odpowiednio przysposobieni specjaliści biblioteczni, śledząc napływające treści, a następnie w związku z tym: tworząc i wprowadzając do sieci stosowne indeksy - dodatkowo łącząc doniesienia o materiałach zarówno cyfrowych, jak też drukowanych. Podobne pomysły pojawiały się już, lecz o ile mi wiadomo było ich niewiele i nigdzie nie zostały przypisane na stałe do żadnego systemu transmisyjnego. A to wszak tylko początek: pierwszy etap.

$\mathrm{W}$ dalszej bowiem perspektywie, syntetyzując te przedsięwzięcia, biblioteki mogłyby z tej informacyjnej magmy wyodrębniać wybrane zakre- 
sy przedmiotowe i zestawiać $\mathrm{w}$ zakresowe segmenty treściowe - na różne sposoby promując je wobec osób potencjalnie zainteresowanych. Zaletą biblioteki (jeśli postępuje prawidłowo) jest bowiem możliwość zgromadzenia w jednym miejscu wszystkich rodzajów informacji (treści), zarówno digitalnych, jak i piśmienniczych. $Z$ zapewnieniem - w dodatku - tym przekazom lepszych warunków użytkowania, aniżeli w sieci. Ponadto zaś, odpowiednio przygotowany bibliotekarz może pomóc $\mathrm{w}$ ocenie jakości dostarczanych materiałów, a nawet - udzielić kompetentnej porady przedmiotowym specjalistom lub innym odbiorcom.

Wychodzi więc na to, że biblioteka może być pożytecznym partnerem w działalności naukowej, w praktyce zawodowej, a także w życiu codziennym. Co więcej: sprzyja pogłębionym kontaktom z ofertą komunikacyjna, zwłaszcza piśmienniczą - w formie o wiele intensywniejszej, aniżeli tylko $\mathrm{z}$ użyciem Internetu.

Zawiera się w tym również poszerzone wyjaśnienie, czemu nadal służą książki w bibliotekach i dlaczego ciągle trzeba je tam gromadzić. Bardzo też możliwe, że pozostaną albo staną się czytelniczymi pracowniami, swego rodzaju laboratoriami - i to biblioteki wszelkiego rodzaju: od publicznych po narodowe.

O ile mi wiadomo, są już biblioteki, które taką rolę pełnią. Ale żeby mówić o tym w szerokim wymiarze, trzeba jeszcze rozstrzygnąć szereg problemów praktycznych oraz znaleźć brakujące odpowiedzi na różne pytania.

Nawet zakładając okoliczności sprzyjające, trzeba jednak przyjąć, że powodzenie konkretnych form i zakresów pracy z książka, inicjowanych przez biblioteki oraz przez szkoły, będzie zależało w znacznym stopniu również od tendencji ogólnospołecznych. Otóż kłopot polega na tym, że tendencje te nie są stałe: ulegają przemianom, podczas gdy zasoby biblioteczne pozostają w zasadzie takie, jakie były. Zagadnienia, które jeszcze niedawno nikogo nie obchodziły, mogą nagle znaleźć się w centrum zainteresowań - a z kolei jest też możliwe, że nastąpią zmiany w kierunku odwrotnym.

O ile wirtualne zaplecze informacji można przeorganizować stosunkowo łatwo, to zasobów piśmienniczych nie da się przebudować równie szybko ani skutecznie. W rezultacie część zgromadzonych księgozbiorów nie będzie już wykorzystywana, natomiast dla zagadnień nowych i reaktywowanych, zaplecze piśmiennicze może okazać się niewystarczające.

To jest kłopot szczególnie dotkliwy dla praktyki bibliotek niewielkich. Ale nie ominie również megabibliotek, ponieważ kompletność zasobów piśmienniczych wydaje się bardzo mało prawdopodobna. Niedostatek przestrzeni może wymusić eliminację części księgozbiorów, nikt jednak nie da gwarancji że później, w jakimś momencie, usunięte zasoby nie okażą się znowu bardzo potrzebne. I wprawdzie w każdych konkretnych 
okolicznościach można zapewne znaleźć rozwiązanie konstruktywne, ale na ogół - doraźne. Nigdy nie ma pewności, że okaże się długotrwałe, a tym bardziej: że sprawdzi się raz na zawsze.

Ponadto dopowiem, że $\mathrm{w}$ tak pojmowanej bibliotecznej pracowni, więc w swoistym laboratorium, potrzebni są inni bibliotekarze. Wobec tego zaś konieczna jest zmodyfikowana koncepcja bibliotekarskiego kształcenia.

Czysto techniczne zawodowe umiejętności bibliotekarskie najprawdopodobniej zejdą na dalszy plan, tym bardziej że liczne procesy zostaną zautomatyzowane. Natomiast pierwszorzędnego znaczenia nabierze tematyczna wiedza zagadnieniowa. Możliwe więc, że wypadnie powrócić częściowo do dawnego wzorca bibliotekarza-encyklopedysty, czyli znawcy naukowych treści. I wprawdzie ten model nie odszedł w całkowite zapomnienie, ale przestał już uchodzić za obowiązujący.

W Rosji taki dawny model bibliotekarza wiedzącego, w znacznym stopniu uosabiał Nikołaj Fiodorow. Zachował się nawet taki obraz, poniekąd symboliczny, namalowany przez Leonida Pasternaka. Oto Nikołaj Fiodorow rozmawia z Lwem Tołstojem i z Władimirem Sołowiowem ${ }^{2}-$ o ile wiadomo: o Bibliotece Rumiancewa. Otóż dzisiaj zapewne nie da się być w pełni kimś takim, jak Fiodorow: partnerem umysłów najtęższych. Ale częściowo?

Poza tym nie ma też szans na stworzenie bibliotecznych pracowni, czyli czegoś w rodzaju laboratoriów, jeżeli intencją uniwersyteckiego kształcenia bibliotekarzy oraz ich zawodowego doskonalenia w miejscach pracy nie będzie przygotowanie dla publiczności kompetentnych doradców. To znaczy takich, którzy profesjonalnie pomogą użytkownikom wybrać oraz udostępnią im użyteczne materiały przedmiotowe. $Z$ ewentualnym uzupełnieniem o bezpośrednią wymianę opinii na sygnalizowane przez tych użytkowników tematy.

W sumie więc zakładam, że tradycyjna rola biblioteki wymaga niejakiego odnowienia. Trzeba mianowicie - jak już sygnalizowałem - przekształcić biblioteki w swego rodzaju laboratoria pracy z książką głównie, albo jeszcze ogólniej: utworzyć w nich aktywne przestrzenie kultury ksiązki.

Tak dookreślona funkcja pozostaje $\mathrm{w}$ zgodzie $\mathrm{z}$ ponadczasową istotą bibliotekarstwa. Jednocześnie zaś odpowiada powinnościom współczesnym: generowania i rozpowszechniania nowych idei - w charakterystyczny dla siebie sposób. Społeczeństwo mogłoby odżegnać się od tego chyba tylko w geście samozagłady.

Nie upieram się, że zasygnalizowana tutaj sugestia to jedyna, albo tė̇ wyłącznie najlepsza prognozowana w przyszłości droga rozwoju bibliote-

${ }^{2}$ Nikołaj Fiodorow (1829-1903): prawosławny filozof i bibliotekarz; Władimir Sołowiow (18531900): prawosławny filozof i poeta; Leonid Pasternak (1862-1945): artysta malarz, ojciec Borysa Pasternaka [przyp. tłum.] 
karstwa. Bardzo możliwe, że pojawią się (pojawiły?) również propozycje inne.

Jednak ponad wszelką wątpliwość, trzeba szukać takich rozwiązań i formuł, które umożliwią bibliotekom pozostanie nadal bibliotekami właśnie. Z uzasadnieniem użyteczności przede wszystkim $\mathrm{w}$ ten sposób, że wciąż będą głównie - nie tylko, lecz także - instytucjami o charakterze księgozbiorowym.

Przeł. z ros. Jacek Wojciechowski

Tłumaczenie artykułu wptynęło do Redakcji 28 lutego $2019 r$.

NIKOŁAJ ZUBKOW

Science and Research Department

M. Rudomino Library of Foreign Literature in Moscow

e-mail: nnzubkov@rambler.ru

\section{THE NATURE OF LIBRARIES AND THEIR POTENTIAL TASKS}

KEYWORDS: Libraries and their nature. Information. Library and librarianship studies. Future tasks of libraries.

ABSTRACT: The author makes an attempt to differentiate traditional and virtual libraries while listing the advantages of the former in the modern world. He also presents a concept of turning libraries into the centers of book culture. 
